\title{
Religion and Ethnicity Traps: Behind the Intention to Vote of Millennial Voters
}

\author{
Jhon Retei Alfri Sandi \\ Department of Government Science, Faculty of Social and Political Sciences, \\ Universitas Palangka Raya, 27111, Palangka Raya, Central Kalimantan Province, Indonesia \\ Corresponding Author: jhonrete@fisip.upr.ac.id
}

\section{ARTICLE INFO}

\section{Publication Info:}

Research Article

How to cite:

Sandi, J. R. A. (2021). Religion and Ethnicity Traps: Behind the Intention to Vote of Millennial Voters. Society, 9(2), 410-419.

DOI: $10.33019 /$ society.v9i2.344

Copyright (C) 2021. Owned by Author(s), published by Society

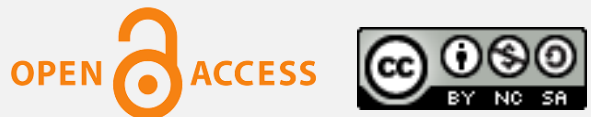

This is an open-access article.

\section{License: Attribution- \\ NonCommercial-ShareAlike (CC BY-NC-SA)}

Received: October 20, 2021; Accepted: November 30, 2021; Published: December 31, 2021;

\begin{abstract}
Millennial voters are a potential community that is a strategic target for pairs of candidates for regional election contestation to reap the coffers of votes. The campaign approach using religious and ethnic sentiments is an alternative strategy. This study looks at religion and ethnicity influencing millennial voters' voting intentions. The research method uses quantitative methods with multiple linear regression. The research sample was drawn randomly according to the criteria so that the answers to 280 respondents were analyzed. The study results found that religion significantly influenced millennial voter intentions, while ethnicity did not affect millennial voter intentions. Millennial voters tend not to be interested in practical politics.
\end{abstract}

Copyright (C) 2021. Owned by Author(s), published by Society. This is an open-access article under the CC-BY-NC-SA license.

Keywords: Election; Ethnicity; Religion; Vote Intention 


\section{Introduction}

At various events of direct election activities by the people, the millennial voter's vote is hotly contested. The percentage of millennial voters who are relatively potential to be a magnet for candidates to concentrate on managing this mass base. Almost all political contestants are vying to garner support to influence the voting behavior of millennials. Millennial voters are unique voters. The behavior of the present situation influences uniqueness due to changing situations and conditions, the development of scientific and technological progress, globalization, and democratization, which change the way of behaving, acting, psychology in making decisions that are different from the previous generation (Zachara, 2020).

The changing situation and conditions of the socio-political, economic, cultural, and security environment due to various advances in information and communication technology affect millennial voters' interpreting political activities and the political system. A person's political behavior is dominantly influenced by an individual's background (Zachara, 2020). The individual background will shape the value orientation to be achieved. Values and goals are shaped in and by the behavioral processes that are a part. The goal is to reach the future, anticipate, relate to the past by considering the history (Varma, 2016). Similarly, religion and ethnicity influence individual attitudes, actions, decisions, and political participation.

Do religion and ethnicity affect the intention to vote for millennial voters? The study of voting provides references to how and why individuals make certain election decisions regarding voting behavior. Profession, ethnic character, gender, caste, age, religion, issue, party, campaign, and leader's credibility determine the democratic decisions of voters. These elements make voter behavior mandatory to making decisions as voting behavior in elections (Gul Said et al., 2021).

\section{Literature Review}

\subsection{Millennial Voters}

The millennial generation, known as the generation born between 1980-2000, has become one of the main weapons in political contestation. The millennial generation grows accompanied by the growth of smart gadgets such as computers, laptops, cellphones, and several other technologies. This generation cannot be separated and tends to have a high tendency towards technology and internet use. Today, the internet is no longer a rare item but a primary need for the millennial generation (Setiawan et al., 2020).

In Indonesia, the millennial generation is considered an important role in politics. From a political point of view, the millennial generation is considered to have a voice that must be taken into account and will be needed in the future. In political education, to achieve good democracy, the millennial generation gets a more mature democratic learning process than the older generation (Setiawan et al., 2020).

Millennial voters who reflect the behavior of the political communication style of young people take advantage of the information disclosure space and advances in information technology through social media networks such as Facebook, Instagram, WhatsApp, YouTube, Twitter, and others. It creates new social, economic, political, and cultural relations for the millennial community and raises narratives and the civilization of young people's political behavior. The millennial generation is critical of what is seen and felt (Alfaruqy, 2019). Be aggressive and responsive, but tend to be careless and act irrationally. 


\subsection{Voter Voting Behavior}

The conception of voter behavior in elections or local elections is closely related to the concept of political behavior. Election behavior to elect representatives of the people who sit in political institutions or leaders is political behavior, considering that political behavior is behavior carried out by an individual or group to fulfill the rights and obligations of a political person. The state requires every individual who fulfills the requirements to carry out the rights and obligations to carry out political behavior, including voting to elect representatives of the people or leaders (Setiadi \& Kolip, 2013).

Voting behavior is a voter's decision in channeling voting rights to candidates in both legislative and executive election contestations. Voting behavior begins with voters' interest in the issues that develop in political communication of candidates, either directly or indirectly, to decide whether to vote or not to vote (Alfaruqy, 2019).

Afan Gafar formulated 4 (four) variables related to voter behavior in elections/local elections, namely: First, socio-religious beliefs (the socio-religious beliefs); Second, party identification relies heavily on psychological issues; Third, the pattern of leadership (the pattern of leadership); Fourth, class and social status (Mufti, 2013). In the millennial group, these variables also influence voting behavior. Religion and ethnicity focus on an in-depth study considering that the two factors of socio-religious beliefs greatly influence the community's social life. It is related to political activities such as local elections, which the people directly carry out in multi-ethnic and multi-religious developing countries.

\subsection{Religion and Ethnic behind the Intention to Vote}

Religion has significance for humans and can influence how humans live their lives. In many people, religion is the basis for knowing oneself and plays a major role in many decisions made by humans (Ishiyama \& Breuning, 2013). Religion remains a bottom-up political force to motivate political movements (Ishiyama \& Breuning, 2013). In the context of local politics, religion is often used as a tool of legitimacy and justification by some elites for their political interests (Halim, 2014). Likewise, in Greek terms ethnos, ethnicity is translated as a nation. It is understood as a community of people who share the same language or culture. The essence of ethnic groups is based on subjective beliefs about a common community. The belief that creates the group and the motivation to form the group stems from the desire to gain political power, stating that: voters choose candidates based on ethnicity because they believe that candidates of the same ethnicity will protect and become patrons. Ethnic identity suggests that choosing a particular ethnic candidate or ethnic party will give voters more benefits than choosing a candidate or party from another ethnic group (Ishiyama \& Breuning, 2013).

Only members of the ethnic group themselves can defend the interests of the ethnic group as a whole. Members of other ethnic groups certainly will not defend themselves. In local political contexts, in the local election, many religious leaders who run for local heads have conveyed religious mobilization, cultural symbols in campaign jargon, charisma exploitation, big names of religious organizations, and other religious education institutions (Harris, 2015). Intentions for voters are beliefs, behaviors, and norms in each individual. Voting at the time of election is a planned intention of each individual depending on the understanding and tendencies of social, political parties, and other psychological decisions (Saleem et al., 2021). People from different civilizations have different views about the relationship between God and humans, individuals and groups, citizens and countries, parents and children, husband and wife, as well as differing views on the relative importance of rights and responsibilities, freedom and authority, equality and hierarchy (Huntington, 2020). Ethnic groupings often 
become the political population, and previous research has stated that tribes contribute to politics, especially in general elections (Saleem et al., 2021).

\section{Research Methodology}

This study will use quantitative methods to measure the effect of the independent variables on the dependent variable, and several independent variables are formed based on the literature study conducted. Data collection and processing using multiple linear regression with SPSS Version 24. The following is the research flow as shown in Figure 1.

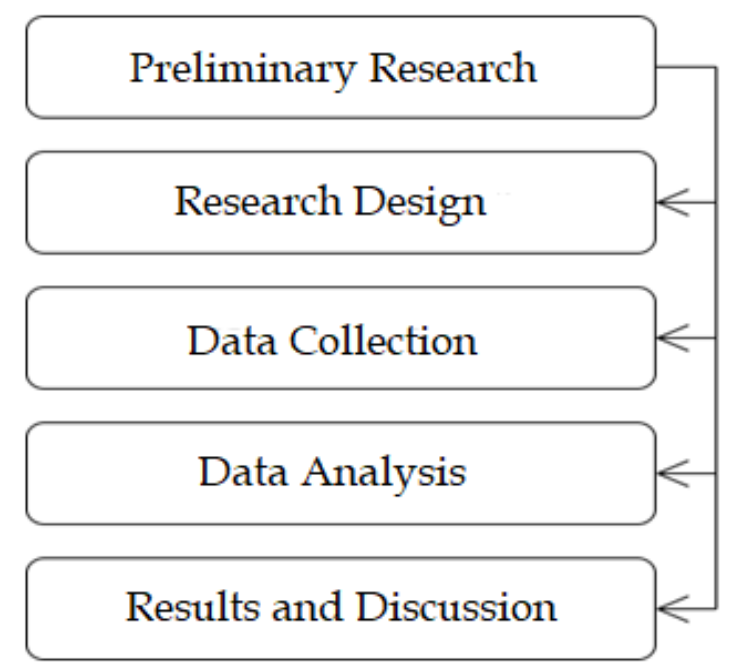

Figure 1. Research Flow

The independent variables in this study were religion and ethnicity, while the dependent variable was voter intention.

Table 1. Research Variable

\begin{tabular}{ll}
\hline Independent Variable & Literature Review \\
\hline Religion & (Huntington, 2020),(Gul Said et al., \\
& 2021) \\
Ethnic & (Saleem et al., 2021) \\
\hline Dependent Variable & Literature Review \\
\hline Voter's Intention & (Saleem et al., 2021) \\
\hline
\end{tabular}

Data were collected by survey method through questionnaires. The distribution of the questionnaire is done by determining the selected sample from the population to obtain quantitative data. The population of this study was students in the city of Palangka Raya. The sample-to-variable ratio suggests a minimum observation-to-variable ratio of 5:1, but a 15:1 or 20:1 ratio is preferred (Hair et al., 2018). This means that although a minimum of five respondents should be considered for each independent variable in the model, 15 to 20 respondents for observations per independent variable are strongly recommended (Memon et al., 2020). In this study, there are two independent variables, namely religion, and ethnicity, so that based on the formula using a ratio of 20:1, a minimum sample of 40 people can be 
determined. Roscoe suggested that sample sizes greater than 30 and less than 500 are suitable for most behavioral studies (Sekaran \& Bougie, 2016).

Data analysis in the early stages was carried out by testing the validity and reliability values of the measuring instrument or Pearson Product Moment correlation instrument. A measuring instrument is categorized as reliable (reliable) if it can measure consistently or stable even though it is proposed at different times (Creswell, 2014). All instruments are reliable if the Cronbach Alpha value exceeds the predetermined limit. The following is equation 2 of Cronbach Alpha.

$$
a=\frac{k}{k-1}\left(\frac{\sum s_{i}}{s_{t}}\right)
$$

Equation 2. Cronbach Alpha

The analytical method used to calculate the influence of religiosity and ethnicity on voter behavior is the multiple regression method using SPSS tools.

\section{Results and Discussion}

Religious and ethnic factors are among the factors that influence voter voting behavior in the local election. These components are included in the socio-religious belief factor group or the socio-religious beliefs. Confidence is a significant variable influencing a person's choice of a political party (Gaffar, 1992, as cited in Mufti 2013).

Examining the significance of the influence of these two factors, the answers to 280 millennial voters aged 17-20 were analyzed from a questionnaire distributed online with the percentage of voters being Protestant Christian 45\% (127 people), Islam 41\% (116 people), Catholic 6\% (16 people), Hindu 8\% (21 people); ethnic identity Dayak 74\% (206 people), Javanese $8 \%$ (23 people), Banjar 9\% (25 people), Batak 8\% (23 people), Balinese 1\% (3 people); and categories aged 17 years $23 \% 65$ people), 18 years 40\% (111 people), 19 years 29\% (80 people) and 20 years $8 \%$ (24 people) as shown in the diagram:

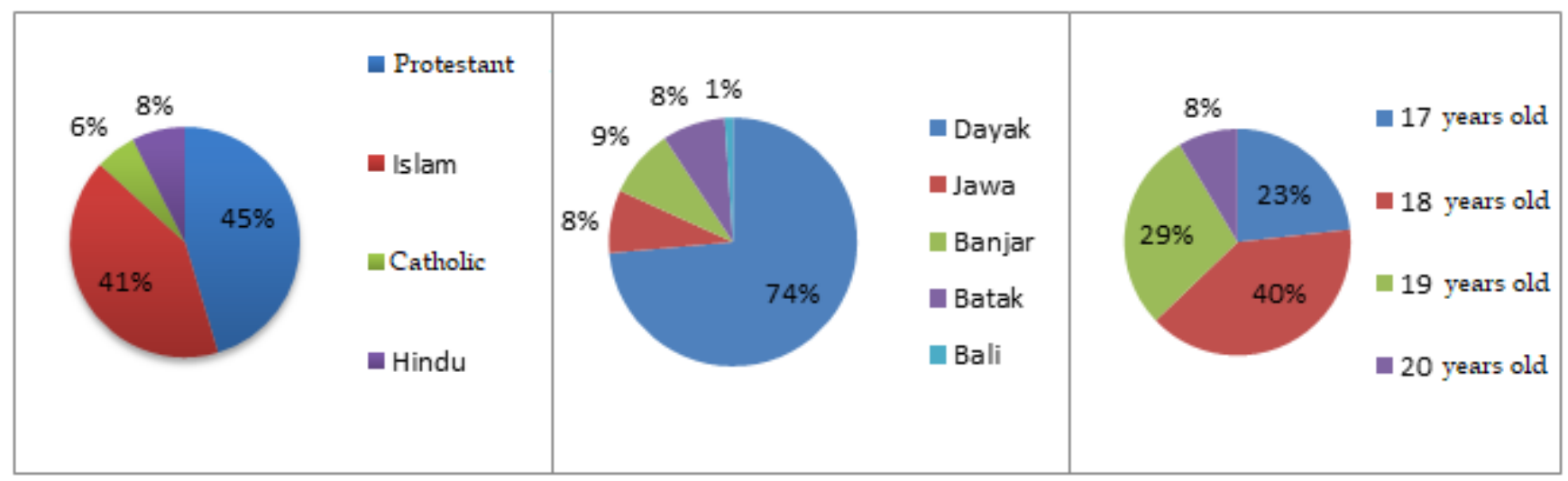

Figure 2. Demographic Distribution Profile of Respondents

Of the 128 respondents in the millennial voter category, 134 respondents had participated in the local election, and 146 respondents had never participated in the local election. Of these 146 respondents, they are included in the beginner voters who have entered the age to vote in the 2024 general election/local election. 
Twenty-one items were asked for the 3 (three) tested variables, namely the Intention variable with 3 (three) question items, the religious variable with 9 (nine) question items, and the ethnic variable with 9 (nine) question items added to the distribution of the demographic profile of the respondent. The results of the compilation of the analysis of respondents' answers can be presented in the following table:

Table 2. Respondent's Answer

\begin{tabular}{|c|c|c|c|c|c|c|c|}
\hline \multicolumn{2}{|r|}{ Intention to Vote Questions } & 1 & 2 & 3 & 4 & 5 & Mean \\
\hline 1 & $\begin{array}{l}\text { As a novice voter, will I vote and exercise my right to } \\
\text { vote in the upcoming } 2024 \text { Governor/Vice Governor } \\
\text { Election? }\end{array}$ & 3 & 3 & 17 & 35 & 222 & 4.68 \\
\hline 2 & $\begin{array}{l}\text { Will I be proactive in overseeing the implementation of } \\
\text { the elections honestly and fairly through the provision } \\
\text { of information/reports of fraud in the elections? }\end{array}$ & 4 & 8 & 29 & 59 & 180 & 4.44 \\
\hline 3 & $\begin{array}{l}\text { Will I actively participate as a volunteer for one of the } \\
\text { candidates? }\end{array}$ & 46 & 34 & 99 & 39 & 62 & 3.13 \\
\hline \multicolumn{2}{|r|}{ Religious Questions } & 1 & 2 & 3 & 4 & 5 & Mean \\
\hline 1 & $\begin{array}{l}\text { The values of the religious teachings that I profess } \\
\text { greatly affect the attitudes and actions of my life? }\end{array}$ & 10 & 6 & 15 & 42 & 207 & 4.54 \\
\hline 2 & $\begin{array}{l}\text { I am happy that people of the same religion are regional } \\
\text { leaders? }\end{array}$ & 32 & 25 & 98 & 45 & 80 & 3.41 \\
\hline 3 & $\begin{array}{l}\text { I will give money, energy, and thoughts to a candidate } \\
\text { with the same religion as me? }\end{array}$ & 124 & 64 & 61 & 9 & 22 & 2.08 \\
\hline 4 & $\begin{array}{l}\text { Will I give political support to a candidate who shares } \\
\text { my religion? }\end{array}$ & 74 & 39 & 104 & 30 & 33 & 2.68 \\
\hline 5 & $\begin{array}{l}\text { Will I join the campaign and volunteer for a candidate } \\
\text { with the same religion as me? }\end{array}$ & 71 & 56 & 106 & 18 & 29 & 2.56 \\
\hline 6 & $\begin{array}{l}\text { Regional leaders, who are not of the same religion tend } \\
\text { to be concerned with their group? }\end{array}$ & 78 & 53 & 79 & 32 & 38 & 2.64 \\
\hline 7 & $\begin{array}{l}\text { Will I allow electoral fraud or violations because the } \\
\text { candidate pair is of the same religion as me? }\end{array}$ & 210 & 33 & 19 & 8 & 10 & 1.48 \\
\hline 8 & $\begin{array}{l}\text { I am happy if a candidate pair of the same religion as } \\
\text { me is elected despite committing a major } \\
\text { violation/cheating? }\end{array}$ & 221 & 24 & 15 & 7 & 13 & 1.45 \\
\hline \multicolumn{2}{|r|}{ Ethnic Questions } & 1 & 2 & 3 & 4 & 5 & Mean \\
\hline 1 & Am I very proud of my ethnic identity? & 2 & 5 & 16 & 42 & 215 & 4.65 \\
\hline 2 & Will I do anything for the benefit of my ethnic group? & 26 & 27 & 93 & 67 & 67 & 3.44 \\
\hline 3 & $\begin{array}{l}\text { Is it fun to live and hang out with people of the same } \\
\text { ethnic group? }\end{array}$ & 12 & 13 & 72 & 64 & 119 & 3.95 \\
\hline 4 & $\begin{array}{l}\text { I am not happy with regional leaders who are not of the } \\
\text { same ethnicity as me? }\end{array}$ & 121 & 64 & 61 & 10 & 24 & 2.11 \\
\hline 5 & $\begin{array}{l}\text { I will give money, energy, and thoughts to a candidate } \\
\text { pair of the same ethnic group as me? }\end{array}$ & 114 & 69 & 57 & 16 & 24 & 2.17 \\
\hline 6 & $\begin{array}{l}\text { Will I join the campaign and volunteer for a candidate } \\
\text { pair of the same ethnic group as me? }\end{array}$ & 75 & 56 & 91 & 24 & 34 & 2.59 \\
\hline
\end{tabular}

Copyright (C) 2021. Owned by Author(s), published by Society. This is an open-access article under the CC-BY-NC-SA license. https://doi.org/10.33019/society.v9i2.344 


\begin{tabular}{|l|l|r|r|r|r|r|r|}
\hline \multicolumn{2}{|l|}{ Ethnic Questions } & $\mathbf{1}$ & $\mathbf{2}$ & $\mathbf{3}$ & $\mathbf{4}$ & $\mathbf{5}$ & Mean \\
\hline 7 & $\begin{array}{l}\text { Will I give political support to a candidate of the same } \\
\text { ethnic group as me? }\end{array}$ & 53 & 51 & 106 & 25 & 45 & $\mathbf{2 . 8 5}$ \\
\hline 8 & $\begin{array}{l}\text { Will I allow electoral fraud or violations because the } \\
\text { candidate pair is of the same ethnic group as me? }\end{array}$ & 207 & 33 & 24 & 0 & 16 & $\mathbf{1 . 5 2}$ \\
\hline
\end{tabular}

To prove the research instruments used, the validity and the reliability of the questionnaire that has been distributed were tested. Validity testing is used to measure the feasibility of the instrument. The validity testing criteria compare the $r$ count with the $r$ table with $=0.05$. If the calculation results of the $r$ arithmetic $r$ table, then the assessment is valid. Still, if the $r$ arithmetic $r$ table is considered invalid, the statement on the questionnaire cannot be used in research. In this study, the value of the $r$ table is 0.0981 .

Table 3. Validity Test

\begin{tabular}{cccccc}
\hline Question & Validity Value & Description & Question & Validity Value & Description \\
\hline 1 & 0.658 & Valid & 11 & 0.753 & Valid \\
2 & 0.729 & Valid & 12 & 0.313 & Valid \\
3 & 0.778 & Valid & 13 & 0.684 & Valid \\
4 & 0.240 & Valid & 14 & 0.600 & Valid \\
5 & 0.620 & Valid & 15 & 0.668 & Valid \\
6 & 0.769 & Valid & 16 & 0.773 & Valid \\
7 & 0.776 & Valid & 17 & 0.785 & Valid \\
8 & 0.765 & Valid & 18 & 0.788 & Valid \\
9 & 0.527 & Valid & 19 & 0.710 & Valid \\
10 & 0.716 & Valid & & & \\
\hline
\end{tabular}

The next step is to measure the reliability of the research instrument. This research instrument's Cronbach Alpha value of 0.892 or $89.2 \%$ can be declared reliable.

Table 4. Reliability Test Results

\begin{tabular}{cc}
\hline Cronbach's Alpha & N of Items \\
\hline 0.892 & 19 \\
\hline
\end{tabular}

After the research instrument has been successfully tested for validity and reliability, the next step is to measure the influence between the independent variables on the dependent variable. In this case, the variables to be tested are the religious and ethnic variables on vote intention. The multiple linear regression method was used to see the effect of two independent variables on the dependent.

Table 5. Variable Test Results

\begin{tabular}{crrrrr}
\hline Model & Unstandarized B & Std.Error & $\begin{array}{c}\text { Standarized } \\
\text { Coefficients Beta }\end{array}$ & Nilai t & Sig \\
\hline (Constant) & 11.112 & 0.484 & & 22.983 & 0.000 \\
Religion & $\mathbf{0 . 0 6 4}$ & $\mathbf{0 . 2 9}$ & $\mathbf{0 . 2 0 3}$ & $\mathbf{2 . 2 2 6}$ & $\mathbf{0 . 0 2 7}$ \\
Ethnic & -0.012 & 0.28 & -0.040 & -0.434 & 0.665 \\
\hline
\end{tabular}

Copyright (C) 2021. Owned by Author(s), published by Society. This is an open-access article under the CC-BY-NC-SA license. 
In Table 4 are the results of the regression test. If referring to the data above, this study found that the religious variable has a $t$-value $>t$ table value $(2.226>1.6504)$ and a sig value $<$ $0.05(0.027<0.05)$, so it can be said that the variable religious influence the intention to vote. While the ethnic variable has no effect because the value of $t$ count $<t$ table $(-0.434<-1.6504)$ then the value of $\operatorname{sig}>0.05(0.665>0.005)$ the direction of the ethnic variable is negative where a negative influence will occur on the intention to choose.

Millennial voters, who in this study were dominated by novice voters, were relatively enthusiastic in choosing and exercising their voting rights in the 2024 local elections (see Table 2 , intention to vote questions, question 1). They are enthusiastic about being proactive in overseeing the implementation of honest and fair local elections (question 2) but are not too enthusiastic about being involved practically in the implementation of volunteering (question 3 ). The results of this study are interesting because the voting behavior of millennial voters shows that ethnic factors have no significant effect on voting intentions in the elections. However, the significant figure is relatively small.

The millennial voter group does not seem to be led by high ethnic (ethnic) sentiments. Although, in general, they are proud of their ethnic identity (see Table 2, ethnic questions, question 1), like to live in a fellow ethnic group (question 3) and provide political support (question 7), they do not want to do excessive political practices related to efforts to win candidates or pairs of ethnic candidates (question 2, 8,9). Millennial voters generally accept regional leaders who are not ethnically similar (question 4) but do not want to engage in practical politics by providing financial support, energy, thoughts, volunteering, and campaigning (question 5,6). In millennial voters, subjective beliefs that build solidarity among ethnic groups as an element of the socio-religious beliefs are not too strong to encourage practical election politics.

That ethnic sentiments that promise candidates of one ethnicity will protect become patrons, provide benefits, defend interests have received less attention from millennial voters in motivating the intention to choose ethnicity as a tool used by individuals or groups to unite, organize and mobilize to achieve goals more political in nature, less influential on the political behavior of millennials (Ishiyama \& Breuning, 2013).

In contrast to religious sentiments, religious values are still very strong in influencing the attitudes and actions of life and intentions to vote for millennial voters (see Table 2, religious questions, question 1). Some millennial groups are very happy with leaders who share their religion, but most also say they are happy (question 2). Millennial voters don't like dirty political practices, winning candidate pairs by justifying them in a way (question 7, 8, and 9). Practical political practices such as giving financial aid, energy, and thoughts and participating in the campaign are less desirable (questions 3, and 5). Suspicion of regional leaders not of the same religion that tends to attach importance to their group is still there, but most think this is not the case (question 6). The millennial group relatively provides political support to candidate pairs of the same religion (question 4).

Religion has an important meaning for humans and can influence how humans live their lives. Religion plays a large role in many decisions that humans make.

\section{Conclusion}

Based on the description above, it can be concluded as follows: (1) Millennial voters who novice voters dominate are very enthusiastic about conducting election activities in the 2024 Pilkada. (2) The socio-religious beliefs factor in the form of religious and ethnic beliefs, in general, affect the life behavior and voting behavior of millennial voters. (3) In the case of this 
study, the influence of ethnic sentiment has no/less significance to the intention to vote for millennial voters. In contrast, religious sentiments tend to motivate voting for millennial voters. (4) Millennial voters are not interested in practical political activities such as giving money, energy, and thoughts and participating in the campaign for candidates/pairs of the same religion or ethnicity. (5) Millennial voters don't like dirty political practices and justify any means to win candidates/pairs of the same religion and ethnicity. (6) Millennial voters tend to be more open and receptive to leaders of different religions and ethnicities.

\section{Acknowledgment}

The author is grateful to express gratitude to those who have had the pleasure of cooperating during this research.

\section{Declaration of Conflicting Interests}

The author has declared no potential conflicts of interest concerning the study, authorship, and/or publication of this article,

\section{References}

Alfaruqy, M. Z. (2019). Perilaku Politik Generasi Milenial: Sebuah Studi Perilaku Memilih (Voting Behavior): Political Behavior of the Millennial Generation: A Voting Behavior Study. Jurnal Psikologi Jambi,4(1), 10-15. Retrieved from https://onlinejournal.unja.ac.id/jpj/article/view/8780

Creswell, J. W. (2014). Research Design: Qualitative, Quantitative, and Mixed Methods Approaches (4th ed.). Singapore: SAGE Publications.

Gul Said, M., Ur Rahman, A., \& Yousufi, M. (2021). The Impact Of Religion On Voting Behavior. Humanities E Social Sciences Reviews, 9(2), 14-24. https:/ / doi.org/10.18510/hssr.2021.922

Hair, J. F., Babin, B. J., Anderson, R. E., Black, W. C. (2018). Multivariate Data Analysis (8th ed.). Boston, Massachusetts: Cengage Learning.

Halim, A. (2014). Politik Lokal Pola Aktor dan Alur Dramatikalnya (Perspektif Teori Powercube Modal dan Panggung). Yogyakarta, Indonesia: LP2B.

Haris, M. (2015). Partisipasi Politik NU dan Kader Muslimat dalam Lintas Sejarah. Al-Tahrir: Jurnal Pemikiran Islam, 15(2), 283. https:/ / doi.org/10.21154/al-tahrir.v15i2.267

Huntington, S. P. (2020). The Clash of Civilizations? The New Social Theory Reader, 305-313. Abingdon, UK: Routledge. https:/ / doi.org/10.4324/9781003060963-50

Ishiyama, J. T., \& Breuning, M. (2013). Ilmu Politik Dalam Paradigma Abad 21. Jakarta, Indonesia: Kencana Prenada Media Group.

Memon, M. A., Ting, H., Cheah, J. H., Thurasamy, R., Chuah, F., \& Cham, T. H. (2020). Sample Size for Survey Research: Review and Recommendations. Journal of Applied Structural Equation Modeling, 4(2), i-xx. https:// doi.org/10.47263/jasem.4(2)01

Mufti, M. (2013). Teori-Teori Politik. Bandung, Indonesia: Pustaka Setia.

Saleem, H., Butt, J., Siddiqui, A., Saleem, S., Lalani, A. S., Bridge, T. C., \& Awang, M. (2021). Behavioural Tendency Analysis towards E-Participation for Voting in Political Elections using Social Web. 12(4), 771-794. Retrieved from https:/ / iaeme.com/Home/article_id/IJM_12_04_065

Sekaran, U., \& Bougie, R. (2016). Research Methods For Business: A Skill Building Approach (7th ed.). Hoboken, New Jersey: John Wiley \& Sons Ltd.

Setiadi, E. M., \& Kolip, U. (2013). Pengantar Sosiologi Politik. Jakarta, Indonesia: PT Kencana. 
Setiawan, A., Sripokangkul, S., Kamil, M., Shidiqi, I. T., \& Hadi, K. (2020). The Influence of Political Actors on Millennial Votes: A Comparative Study of Indonesia, Thailand and the Philippines. Journal of Research and Development Institute, Rajabhat Maha Sarakham University, 7(June), 563-576. Retrieved from https://so03.tcithaijo.org/index.php/rdirmu/article/view/240319

Varma, S. (2016). Teori Politik Modern. Jakarta, Indonesia: RajaGrafindo Persada.

Zachara, M. (2020). The Millennial Generation in the Context of Political Power: A Leadership Gap? Leadership, 16(2), 241-258. https:// doi.org/10.1177/1742715019885704

\begin{abstract}
About the Author
Jhon Retei Alfri Sandi obtained his Doctoral degree in Social Science from Universitas Merdeka Malang in 2016. The author is an Assistant Professor at the Department of Government Science, Faculty of Social and Political Sciences, Universitas Palangka Raya, Indonesia.

E-Mail: jhonrete@fisip.upr.ac.id
\end{abstract}

Copyright (C) 2021. Owned by Author(s), published by Society. This is an open-access article under the CC-BY-NC-SA license. 